\title{
AGROECOLOGICAL FARMERS' MOVEMENT IN BRAZIL. A PRACTICAL EXAMPLE OF MULTI-STAKEHOLDER APPROACH FOR RURAL DEVELOPMENT
}

\author{
O MOVIMENTO DOS AGRICULTORES AGROECOLÓGICOS NO BRASIL. UM EXEMPLO PRÁTICO DE \\ ABORDAGEM MULTI-STAKEHOLDERS PARA O DESENVOLVIMENTO RURAL
}

Andrea PRONTI ${ }^{1}$

Artigo recebido em 14/05/2018 e aceito em 16/07/2018

Keywords:

Agroecology;

Brazilian Farmers

movements;

Food Sovereignty;

Multi-Stakeholder

Approach;

Smallholding

Agriculture,

Minas Gerais.

\section{Palavras-chave:} Agroecologia; Movimentos dos Fazendeiros Brasileiros; Soberania Alimentar; Abordagem MultiStakeholders; Agricultura de Pequenos Produtores, Minas Gerais.

\begin{abstract}
A B S T R A C T
International agendas claimed that a farmer centered approach would help in coping with food insecurity and environmental challenges toward a new sustainable paradigm of food production worldwide. Both bottom-up and multi-stakeholder participation has been suggested in order to improve effectiveness and implementation of rural development policies tailoring them to local needs and peculiarities. Farmers' movements in Brazil have been using this approach for years, introducing agroecology to improve socio-economic and environmental conditions with the aim to obtain territorial food sovereignty for a sustainable production of food. This paper explores this issue focusing on a real case of multi-stakeholder intervention based on agroecology for rural development of the East Region of Minas Gerais in Brazil. The area is peculiar for both socio-economic difficulties of smallholding farmers and for strong environmental fragility. An international cooperation project between Italy and Brazil permitted to boost local stakeholder farmers' networks for an endogenous agroecological transition. Key elements of the intervention are underlined in the paper in order to describe better this practical successful experience.
\end{abstract}

\section{R E S U M O}

As agendas internacionais afirmavam que uma abordagem centrada no agricultor ajudaria a lidar com a insegurança alimentar e os desafios ambientais visando à construção de um novo paradigma sustentável de produção de alimentos em todo o mundo. A participação ascendente e multiparticipativa foi sugerida para melhorar a eficácia e a implementação das políticas de desenvolvimento rural adaptando-as às necessidades e peculiaridades locais. Os movimentos de agricultores no Brasil têm usado essa abordagem há anos, introduzindo a agroecologia para melhorar as condições socioeconômicas e ambientais, com o objetivo de obter a soberania alimentar territorial para uma produção efetivamente sustentável de alimentos. Este artigo explora essa questão com foco em um caso real de intervenção multistakeholder baseado na agroecologia para o desenvolvimento rural da Região Leste de Minas Gerais no Brasil. A área é peculiar tanto pelas dificuldades socioeconômicas dos pequenos agricultores quanto pela forte fragilidade ambiental. Um projeto de cooperação internacional entre a Itália e o Brasil permitiu impulsionar redes locais de agricultores interessados em uma transição agroecológica endógena. Os principais elementos da intervenção estão sublinhados no artigo, a fim de descrever melhor esta experiência próspera de sucesso.

\footnotetext{
1 Department of Economics and Management, University of Ferrara (Italy). Via Voltapaletto 11, Ferrara- Italy. Research Institute on Sustainable Economic Growth of The National Research Council (Italy). Via Real Collegio 30, Moncalieri (T0) Italy. E-mail: andrea.pronti@ircres.cnr.it.
} 


\section{INTRODUCTION}

Despite the important improvements obtained in the last century in agriculture that enhanced markedly the satisfaction of feeding needs, hunger and poverty are still impressive worldwide. About one every nine persons in the world suffers for chronic undernourishment, equal to almost 805 million people in the world, principally from the so labeled "South of the World" (FAO, 2014). Since the "90s international agendas are stating the necessity of interventions to eradicate extreme poverty and food insecurity, suggesting new methods of rural development actions based on small farmers and multistakeholder approaches. Even that, not many interventions in the international cooperation sector assumed such bottom-up and participative approaches, whereas several farmers' movements around the world started to self-organizing themselves pushing agroecology to improve socio-economic and environmental conditions in rural areas, working jointly with NGOs, Universities and local institutions.

Various important experiences in Agroecology transition in Latin America demonstrated that a participative method of making agriculture opposite to the conventional approach introduced by the Green Revolution is possible (Rosset et al, 2011). In Brazil during the last decades farmers' movements have developed effective models of intervention at several scale pushing the country at the forefront in Latin America in struggling for farmers' rights and proposing an alternative paradigm for activities and method for sustainable food productions.

This study take form after the Workshop "ITALIA-BRASILE. Globalizzazione, Politiche Pubbliche e Sviluppo Territoriale" held in Bologna (Italy) on the $16^{\text {th }}$ and 17th of February in 2017 in which various scholars from both Italy and Brazil gather together in order to re-think how local territories can act as elements of sustainable development in the Agri-food sector. In this paper are underlined the Brazilian farmers' activities, that could give new interesting suggestions to cope with similar problems in other territories. In Italy agriculture, even if it is not the main sector of the country, remain important for quality and excellence food with important valuable Agri-food districts exporting typical made in Italy products all over the world. Even in Italy agriculture is facing new challenges linked to environmental and climate problems and more attention will be put by institutions and policy makers in sustainability and rural development issues.

One of the main questions in this cases is: "How can obtain scaling-up for sustainable agriculture activities?", "Do past experiences give some suggestions to do it?".

In this paper it is described a rural development process arose from an international cooperation project between Italy and Brazil, that have supported an interesting experience of networking building for rural development, in which it was adopted a multi-stakeholder approach to push agroecology in order to boost sustainable development in the East Region of Minas Gerais (MG), a rural area characterized by social difficulties and strong environmental fragility. 
This paper tries to understand how agroecology could be implemented and spread it up at regional scale analyzing a practical case of success. This paper is the result of a four months on field research carried out during the project in which the author has taken directly part as an external observer to various activities of the project such as internal meetings, conferences, workshops and other networking activities undertaken with the stakeholders of the project. During the observation activities the author had directly the chance to interview using an ethnographic approach with open ended questions key informants of the process of agroecological networking building under creation such as farmers, farmers' movements leaders, trade unions leaders, project managers, agroecologists and other experts from universities and Non Governamental Organizations (Ngos), informal farmers' groups, farmers' associations and cooperatives. The results of the discussions and of the observations have been implemented with projects documents and grey literature such as reports and local newspapers. After the end of the project it has been proposed a semi-structured interviews to the local managers of the Brazilian Ngo which carried out the activities in order to understand the follow-up of the project itself.

The paper is structured as follow. First this study contextualizes the sphere in which smallholding agriculture and agroecology intersect themselves introducing also the concept of Food Sovereignty, then it has been analyzed agroecology and farmers' movements advocacy in Brazil, and finally it is traced the case of the international cooperation project activities, categorizing all the principal stakeholder that intervened in the process. Findings of this study suggest that multistakeholder intervention for rural development can give continuity to activity empowering and supporting local stakeholders, but further deep studies on multi-stakeholder approach in rural development are needed in order to find key elements to replicate successful factors to support agroecology scaling-up and Food Sovereignty in food systems worldwide.

\section{SMALLHOLDING AGRICULTURE AND AGROECOLOGY}

The vast majority of farms in the world are managed at small scale level directly by the household members as part-time or full time farmers. People who live in rural areas in the world are around 3.37 billion equal to almost half of the global population, whereas the farms which are managed at family level are 500 million, which represent the $85 \%$ of the total worldwide agricultural production units (ELVER, 2015; FAO, 2016). Smallholding agriculture is actively contributing to both natural resources management and food security worldwide, even with the access to only the $20 \%$ of the world arable lands (ELVER, 2015; PIMBERT, 2008; IFAD \& UNEP, 2013). Small scale agriculture, using surfaces lower than $2 \mathrm{HA}$ of land, produce over than $70 \%$ of the total food production in Africa, $80 \%$ in Asia and Pacific area and 41\% in Latin America, providing most of the grains, tubers, legumes and vegetables on 
local markets (IFAD \& UNEP, 2013; ALTIERI, 2009). Most of them adopt "low resource" farming techniques based on the use of local resources because of high difficulties in access to capital and finance due to low income and rural poverty that they experience. In fact, nevertheless the breakthroughs gained in the last century in terms of food productivity, the people living in undernourished chronic conditions are still 780 million (FAO, 2015a) and people living in extreme poverty, with less of $1.25 \$$ per day, are 1.4 billion. Around three-quarters of them are residents of rural areas of poor countries (IFAD, 2011).

There is still not a universally accepted definition of small farming, the principal meaning cope with the amount of capital and productive surfaces available by farmers, volume of sales, family income and the direct participation of smallholding members in both the management and workforce of the farm (NAGAYETS, 2005). These categorizations could be misleading, because also modern and high tech farms could present these characteristics, so other factors must be taken into account to define smallholding agriculture such as marginalization in terms of accessibility, policies, resources, technologies, information and assets (IFAD \& UNEP, 2013). Differences among farms of small scale must have been done also in the socio-economic and environmental contexts in which farms operate and the challenges which they have to cope with. For example, American or West European farms are extremely different to Asian, African or Latina American farms in terms of finance and capital access, productivity, income generation, self-consumption, food security, demographic growth, infrastructures, transports, level of education, ecosystem services availability, climate changes, environmental pressures and many other factors. In accordance with Brazilian law, this paper, will refer at smallholding agriculture considering a small farm an agricultural unit managed by family members who represent most of the farm workforce, with small productive areas and characterized by low income, few means of production and limited financial access (PRESIDENCIA DA REPUBLICA BRASILEIRA, 2006).

Since the Rio Earth Summit in 1992 the international community has recommended, and reaffirmed in the world conference Rio +20 held twenty years later, that smallholding agriculture must assume a crucial role in fighting both hunger and environmental impacts worldwide in order to guarantee sustainable development (RIO DECLARATION, 1992; RIO DECLARATION, 2012). According to Agenda 21 objectives the approach of agriculture and food policies should have been with a "farmer centered" approach, considering small farmers as the main drivers of environment and landscape keeper through sustainable food production activities (CAPORALI, 2008). This approach has been jointly sustained with the use of agroecology, already internationally recognized by both scholars and agencies as being the approach by which obtain sustainability global agricultural systems coping with the new upcoming ecological and climatic challenges of planet Earth (DE SCHUTTER, 2010; GODFRAY ET AL., 2010). 
The definition of agroecology was born in the '30s of the twentieth century principally linked to agronomic studies, its meaning evolved during time as the scientific community started to adopt a multidisciplinary method of studying food and agricultural problems in third world countries, inspired by the practical work of NGOs and grass roots movements that considered rural problems in a systemic way (WEZEL et al, 2009). During the past century agroecology began to be accepted as a bulk of multidisciplinary knowledge and practices to get sustainability in agriculture, not just in a productive and agronomic point of view, but also considering its social, economic and environmental dimension, finally defining it as a Science, a practice and a movement (WEZEL et al, 2009; DALGAARD et al, 2003).

The most shared definition describes agroecology as the application of ecological principles to the study, design and management of sustainable agroecosystems with the aim of stabilize them, increasing their resilience and resistance, reducing needs of external inputs (matter and energy) by the creation of benefic biological synergies in the farm agricultural system and considering the farmer as part of the system and not just a simple controller of it (ALTIERI AND NICHOLLS, 2005; GLIESSMAN, 1990, ODUM, 1966). Agroecological practices are peculiar for each local ecosystem and they are adapted to it being based on the local environmental and socio-economic conditions, but all of them share the principal aims of increasing soil regeneration, biodiversity and optimization of the use of local natural resources with the intensification of the agroecosystem complexity and the interactions among its components (ALTIERI \& TOLEDO, 2011).

The most used agroecological practices are knowledge intensive management based on scientific or traditional methods which include no-tillage, intercropping, crop rotation, soil protection, agroforestry, integration of animals breeding, integrated pest management, own made green pesticides and fertilizers. Agroecology methods are multifunctional, low capital intensive and very flexible to every geographical contexts allowing to improve the generation of income in rural areas by both agricultural diversification and reducing cost from external inputs, at the same time it permits to reduce environmental pressures due to conventional agricultural activities (ALTIERI, 1991). The principal element of diversity from conventional and industrial agriculture is the interactions of the elements inside the agroecosystem such as a natural ecosystem in which human beings are part of it and not just mere agricultural controllers. In this term agroecology differs totally also to organic agriculture, which it limits only its intervention to the use of some damaging chemical inputs in the agroecosystem accepting others considered less dangerous for the environment and accepted by private international certifier authorities (IATP, 2013).

Agroecology during the last century changed its sphere of observation and application, passing from being considered as a mere branch of agronomy focused on the study of agroecosystems to a new complex instrument of analysis for the obtainment of sustainability into the global Agri-food system as the ecology of the global food systems (FRANCIS et al, 2003). In this transition other discipline of 
studying enlarged the focus of agroecology from the micro view of field production in which principally agronomy and ecology have been considered. The addition of sociology, anthropology, economics, geography and philosophy in the studies of agroecology extended the scale of analysis from the farm to the world introducing a systemic approach and becoming the contemporary integrated and multidisciplinary branch of knowledge studying sustainability in food production and rural development (WEZEL \& SOLDAT, 2009).

\section{AGROECOLOGY IN LATIN AMERICA}

In Latin America agroecology has consistently widespread over the last 30 years thanks to its high adaptability to each rural condition with important positive results (ALTIERI \& TOLEDO, 2011). Since the early 1980s many agroecological projects have been developed all over Latin America by NGOs first combining traditional agricultural knowledge with scientific agronomic innovations, then grass roots farmers' movements adopted these practices adding socio-political stances in defense of peasants and indigenous rights counterpoising what became the concept of "Food sovereignty" to the "Green Revolution" paradigm (UPHOFF, 2002). Several important experiences in terms of socio-economic and environmental improving in rural areas have been developed in Brazil, Andean Region, Cuba, Mexico and Central America (HOLT-GIMÉNEZ, 2002; PRETTY ET AL., 2006, SOCLA, 2012; DE SCHUTTER, 2010). During years agroecology obtained a strong scientific support of Latin American academic community receiving backing of governments and national agriculture agencies (FAO, 2016), an example is its inclusion in the agenda for integration within Mercosur and Community of Latin America and the Caribbean posing the region at the forefront for the fight against hunger and toward sustainability (FAO, 2015a).

Farmers had an active role in the extension of agroecology in Latin America through the peasant process of technological and technical innovation called "Campesino a Campesino" (CAC), farmer to farmer in English, which had taken place for the first time in Mesoamerica more than 30 years ago (ALTIERI \& TOLEDO, 2011). CAC is a process of generating and sharing capability based on a horizontal transmission of knowledge and information through farmer acting as promoters who share the solution they found to practical problems, with other farmers who may cope with the same difficulties, during on-field applied workshop. Then, farmers who received this new knowledge, will share these solutions with other farmers in their community operating as a multiplier effect agent (ROSSET et al, 2011). It is a bottom-up and participatory approach that differently to conventional diffusion of knowledge process in which a technician frontally shows the use of fertilizer or pesticides. By the CAC method farmers are more stimulated by trustworthy colleagues, who can help rapidly in finding solutions through small- 
scale experiments and the introduction of new methods to local needs linked to peasant cultures and identities, working as a real "peasant pedagogy" (ROSSET ET AL., 2011).

CAC started from small and local bases from farmer organizations and then it spread at national level for its high flexibility and efficacy in various Central American countries, creating a CAC network that operated also internationally consolidating in a farmers' movement that claim for agrarian reforms, rights and improvements in rural living conditions (HOLT-GIMÈNEZ, 2008). In Nicaragua and Cuba the experience of the CAC was very impressive with thousands of farmers who were invested by its activity and became active actors thanks also to the strong sustain of NGOs, Universities, national farmer organizations and national Governments of the two country that both experienced a common process of strong national farmer participation in agriculture development, Nicaragua during the Sandinista Revolution and Cuba after the "Periodo Especial" (ROSSET et al, 2011; HOLT-GIMÈNEZ, 2008; NELSON et al, 2009).

The historical success of CAC in vast areas of Latina America represents a successful multistakeholder strategy for the scaling-up of agroecology for the improvements of socio-economic and environmental conditions that can be replicated in the upcoming scenarios which next challenges faced by the majority of farmers in the continent.

Although various researches demonstrated the good results achievable through agroecology, its use is not really considered yet as a leading strategy of intervention for sustainable agriculture at international level and it is still relegated as a practice adopted mainly in specific international cooperation projects (PRETTY et al, 2006; HOLT-GIMÉNEZ, 2002), even if in the international debate it has been claimed that agroecology could be one of the best solutions for sustaining food provision globally and conserving natural key resources at the same time (DE SCHUTTER, 2010). In the next years it should not be probably an option, but an inevitable choice for global food security. In Western Countries agroecology has not yet been applied even if now various discussions are still open on that, whereas Latin America as already passed through this path since several years building up a noteworthy quantity of knowledge and experiences which could be adapted for the transition of other countries toward a path of a sustainable global food systems (FRANCIS et al., 2003).

\section{AGROECOLOGY: A NEW PARADIGM FOR RESILIENCE IN GLOBAL FOOD SYSTEMS}

After sixty years the effects of the Green Revolution are evident, if on one hand it brought a massive increase in agricultural and food productions all over the world, on the other hand the consolidation of this agricultural revolution did not achieved the goal of eradicate famine and food poverty (IFAD, 2011; FAO, 2015; MAZOYER \& ROUDART, 2006), whereas the Green Revolution 
principally resulted in land and wealth concentration, mass migration to urban settlements and enormous environmental impacts (SHIVA, 1991; PATEL, 2009).

Green Revolution boosted inequalities among industrial and small farmers all over the world because of the new international market structure that emerged, characterized by high capital intensity and extreme competition that pushed out of the market many "not efficient" small farms. Since the 80's, arose a new food regimes characterized by big multinational corporation that started to occupy the majority of the global value chains acting as an oligopoly, influencing both international trade and institutions committed to control and policy making (HOLT GIMÉNZ \& SHATTUCK, 2011). Market concentration, chemical input oligopolies, declining biodiversity of crops, market volatility and a strong intrusion of speculative financial markets had further worsen rural population in large parts of the world (MAZOYER \& ROUDART, 2006). An example is the recent food crisis occurred in 2007-2008, when food prices have suddenly increased almost doubling in only one year, without a general reduction of global agricultural yields (FAO, 2009a; SHAH, 2008). During this crisis more than one billion of people had been pushed into hunger and poverty principally because of a set of external factors influencing international food prices totally external to agricultural productions such as oil prices, massive biofuels crops expansion and futures markets speculation on food commodities. The recent food crisis affected people of the lowest classes, principally in poor countries where food expenditure is an important components of family incomes, dragging millions of people into a spiral of chronic malnutrition and poverty (UN, 2011).

Even if the impressive increase in food prices small farmers did not benefit from that, whereas other big actors of the global food value chain had earned from this situation such as big industrial farmers, commercial actors and financial speculators (FAO, 2009b). This situation of uncertainty and external influence of food markets seems had become structural and it would further increase because of the constant growing world population and the change in food consumption pattern of new affluence countries, which would further expand the difficulties of global food supply with the risk of dangerous and turbulent social conditions (GODFRAY et al, 2010). Global food security would probably worsen outlining a new era of food scarcity and tightening, due to important environmental problems such as water shortages, soil erosion, declining of farmlands, climate change and environmental fragility which could bring to transnational conflicts and to the establishment of a new geopolitics of food based on strategic natural resources control similar to what is occurring in Africa with land and water grabbing (BROWN, 2011; UN, 2011).

The externalities and market failures which caused environmental degradation and social impacts of the agricultural capitalist paradigm based on industrial production and food commodities markets has encouraged the formation of lots of farmers' movements at local, national and transnational level to struggle for improving social and environmental conditions of the agriculture sector, proposing a 
new paradigm of agriculture based on fair trades, environmental sustainability, agroecology and local food security (HOLT GIMÉNZ \& SHATTUCK, 2011). One of the powerful international network of farmers' movements, 'La Via Campesina', introduced the concept of Food Sovereignty which is the cornerstone of a new paradigm of food production based on the democratization of the global food system as the right of each nation or territory in deciding its own way of production of healthy and sustainable food to feed its population (BEUCHELT \& VIRCHOW, 2012). Food Sovereignty focus on the centrality of small farms, agroecology and access to food as an inalienable right for the reduction of market distortions due to oligopolies of few big corporations wielding the power in the actual global food system, with the aim of providing stable food productions and preserving global natural resources fundamental for the provision of environmental services extremely important for sustaining future generations (HOLT-GIMÈNEZ \& PATEL, 2010; PIMBERT, 2008).

This new paradigm highlights the centrality of small holding farmer communities and local markets in achieving food sustainability, considering its multidimensional form (environmental, social and economic) and scale (local and international), through a 'farmer driven' self-determination of food production and consumption in which farmers and consumers would democratically unite to participate actively for a new way of the global food system (PATEL, 2009; DUPRAZ \& POSTOLLE, 2013). This new paradigm strictly oppose the neoliberal form assumed of the global food system asking for a renovation of it in a more equal and fair model (ROSSET, 2003; ROSSET, 2008). The Food Sovereignty approach substantially distinguishes from 'Food Security' that is commonly used in the international agendas in food policies, in fact the latter does not define how to get fair levels of adequate basic nutrition, whereas Food Sovereignty highlights a structural intervention in the actual conception of producing, trading and consuming food with a strong political critic to the actual management of the global food regime (HOLT GIMÉNZ \& SHATTUCK, 2011).

Agroecology has been taken as another reference point of opposition to the actual neoliberal paradigm of the global food system that together with Food Sovereignty inspired several farmers' movements, especially in Latin America, to claim radical changes in food systems against big agribusiness power, monocultures, biotechnologies and chemical agriculture for rural development, conversely proposing a concrete alternative scheme based on the centrality of the local scale, environment conservation, rural development and smallholding farming in a framework of cooperation between different stakeholders operating at different level of the food systems (ROSSET, 2003; ROSSET, 2008; PIMBERT, 2008).

The key of success for a concrete change in the actual paradigm is the scale at which agroecology, and consequently Food Sovereignty, could be affirmed and extended. Main critics to this model affirm that broad agroecological system would not have the strength to sustain the global food production, whereas the scaling-up of agroecology through CAC, local networks and other multi- 
stakeholder intervention have demonstrated that this affirmation is misleading for some regional cases (DE SCHUTTER, 2010; ROSSET et al, 2011). The successful agroecological experiences which occurred in several Latin American countries, and principally in Cuba and Brazil, were characterized by an impressively lower level of financial and capital resources available for agricultural development than the amount of resources used for the massification of the Green Revolution practices all over the world. The positive socio-economic and environmental results of those experiences have well documented how agroecology can represents a possible alternative of a resilient food production worldwide (HOLT GIMÉNEZ \& ALTIERI, 2013; ALTIERI et al, 2012).

\section{SMALL FARMER NETWORKS AND AGROECOLOGY IN BRAZIL}

Brazil is one of the most important Latin American countries in terms of economic growth and commodities export in the world. Even if in the last decades Brazilians had improved their social conditions, poverty continue to be a critical issue for the country. People living below the poverty line in 2014 were still 15 million and 7.5 million in extreme poverty (below 1.69\$ per day), in 2001 they were respectively 44 and 23 million of people (WORLD BANK, 2017). Brazil is also still characterized by a disproportionate distribution of wealth, in fact the richest quintile of the population detains the $56 \%$ of the total income of the country, whereas the lowest quintile detains the $3.6 \%$ of it, in 2001 the share of income for the highest and the lowest quintile were 63\% and 2.4\% (WORLD BANK, 2017). Extreme social differences are marked within the country between rural areas and urban centers ${ }^{2}$ (IBGE, 2011), and among social classes, gender and ethnic origin ${ }^{3}$, in which vulnerable classes cope with strong difficulties in access to healthcare, basic nutritional level, education and basic needs (IBGE, 2000; IBGE, 2010; IBGE, 2012).

Historically Brazil is a nation with a strong agricultural vocation because of its vast, rich and diverse territory, but since the institution of the modern federal state it experienced long and harsh conflicts between big landowners and small farmers for the management of lands all over the country (PAULINO, 2014). Nowadays there have still been reported various cases of slave-like labour conditions and wide outlaw land occupation, the so-called 'Grillagem', that consists in large estate possessed without proper certifications by big landowner descendants of the colonial Portuguese bourgeoisie which correspond almost to $12 \%$ of the Brazilian territory (DE SCHUTTER, 2009). Brazil has

\footnotetext{
${ }^{2}$ According to IBGE census in 2010 the $25 \%$ of Brazil population had an income not higher than $188 \mathrm{R} \$$ (equal to $60 €$ ) and the $50 \%$ of the population not higher than $375 \mathrm{R} \$$. The average income for urban inhabitant were $455 \mathrm{R} \$$ whereas for rural inhabitants were $175 \mathrm{R} \$$. In the countryside the $21 \%$ of people lived with a maximum income of $70 \mathrm{R} \$$ (around $23 €$ ), the $38 \%$ with a maximum income of $180 \mathrm{R} \$$ and the $66 \%$ with $375 \mathrm{R} \$$ (IBGE, 2011).

${ }^{3}$ Afro descendants and mixed race people earn on average the $44 \%$ less of the income of a European descendant, women receive on average the $33 \%$ less of men (IBGE, 2010). Afro descendants, indigenous and Asian descendants are the most fragile social segments with reduced access to health basic services, lower education and lower incomes compared to European descendants although they represent the majority of Brazilians equal to the $50.7 \%$ of the total population (IBGE, 2011; IBGE, 2012).
} 
experienced a massive industrialization in the '30s of the last century with large migrations from rural areas toward the industrial center of that time, during the '70s with the arrival of the Green Revolution it began a big industrialization phase of the agricultural sector that caused land concentration and massive scale production for the international markets (MARTINE \& MCGANAHAN, 2010; LOSANO, 2007). Nowadays rural population is less than $10 \%$ of the total and agricultural sector represents only $5 \%$ of the total economy of the country, but agriculture continue to play a strategic role for the country because Brazil is one of the largest commodity exporter and food producer in the world (WORLD BANK, 2013; WTO, 2013).

Agriculture in Brazil is dominated by two opposite model of production, one represented by export oriented and capital-intensive big companies trading commodities worldwide cause of strong environmental damages, deforestation and pollution and the other embodied by small farming (ROCHA et al, 2012).

Nevertheless, the imbalance in land distribution, smallholding agriculture is the backbone of the Brazilian food sector being the $84 \%$ of total agriculture production units and principal driver of Brazilian domestic food production and agricultural employment, even though small farmers occupy only $24,3 \%$ of the total cultivated areas (IBGE, 2006). There are 4.3 million of small farms which produce $87 \%$ of manioc, $70 \%$ of beans, $46 \%$ of maize and $38 \%$ of coffee and good part of animal production with a total value of $38 \%$ of the agricultural production value of the country, small farming occupies almost 12,3 million of workers equal to $74 \%$ of employed in the whole sector (IBGE, 2006).

Since the '90s Brazilian governments started important and innovative programs to improve food security and rural development. During Workers' Party (Partido dos Trabalhadores) governments in 2003 with the program "Zero Hunger" have been launched an impressive intervention to eradicate hunger and extreme poverty using as a central driver of change the small farming sector. This program intervened with a multi-sector approach pushing for an intensification of the agrarian reform and boosting smallholding agriculture improvements through commercial agreements with supermarket, public procurement agreements, technical and financial support and minimum guaranteed prices in order to provide local markets with local and healthy food (DA SILVA, 2010).

"Bolsa Familia" program was a vast transference of money to people below the poverty line, help for children education or in form free access to basic medical treatments it has been one of the most impacting of "Zero Hunger" policy program (ARANHA, 2010). The National Program for Familiar Agriculture (Programa Nacional da Agricultura Familiar - PRONAF) consisted in the creation of special line of credit for farmers without guarantees and with financial difficulties in order to sustain investments and income generation (DA SILVA, 2010). The Food Acquisition Program (Programa de Aquisição De Alimentos - PAA) was a program of public purchasing of food products to be redistributed for free to vulnerable people from smallholding farmers with economic difficulties (PERACI \& 
BITTENCOURT, 2010; PRESIDENCIA DA REPUBLICA BRASILEIRA, 2012). The Family Farm Price Guarantee Program (Programa de Garantia de Preços da Agricultura Familiar - PGAPAF) allowed smallholding farmers to sell their products at a minimum price in local markets, equal to the average price of the regional markets, in order to stimulate product diversification and local consumption (PRESIDENCIA DA REPUBLICA BRASILEIRA, 2006b). One of the most innovative program has been the National School Food Program (Programa Nacional de Alimentação Escolar - PNAE), known as "Merenda Escolar", a large program of food procurement for school feeding by which at least the 30\% of food distributed in schools must be provided by local small farmers with the double aim of improving diets for children, fighting undernourishment and sustaining small farming in food direct selling (SOARES et al., 2017; PRESIDENCIA DA REPUBLICA BRASILEIRA, 2009).

The implementation of those policies allowed good results in terms of poverty reduction cutting more than half of it, in rural areas poverty have been reduced from 15 to 8 million of people (DEL GROSSI, 2010). Nevertheless, 66 million Brazilians still live in food insecurity (OXFAM, 2010; IFAD, 2011).

Smallholding agriculture have been a cornerstone of the governmental intervention in "Zero Hunger" program and of its impressive results (DA SILVA, 2010; DE SCHUTTER, 2009), but in spite of their new importance for the national agricultural sector, small farmers face many difficulties with high risks of productions, bottle neck on commodities value chain and low margin of profits that jeopardize their possibility to gain fair socio-economic conditions (HESPANHOL, 2008). Besides that, the agrarian question has never been truly faced by the Brazilian governments leaving the actual situation with a disproportionate distribution of land and an inflamed open debate on the necessity of a modern agrarian reform (PAULINO, 2014).

Despite its contradictory and conflicting system Brazil is one of the few countries in world to have a specific definition of "smallholding farmers", as stated by Brazilian federal law no 11.326 smallholding farmer is defined as a farmer who have a small area (depending on the different extension defined by each Brazilian state) by which his/her family gain the main source of income using principally familiar labor for agricultural productions (PRESIDENCIA DA REPUBLICA BRASILEIRA, 2006).

During time rural social movements played an increasing role in offering an alternative paradigm of rural development creating many national and international organizations and food networks, MST Landless Movements or Ecovida network are just some examples of how rural activism have been able to influence consistently the institutional politics of the nation (LAMINE et al, 2012; DELGADO, 2008). Since the 70's rural movements conformed as multi-actor organization in which academics, NGOs, Christian congregation, trade unions and political activists joined small farmer 
struggles and claims, embracing agroecology not just as a practice but as a new paradigm for a fair future development of the country (WEZEL et al, 2009; ALTIERI, 1999).

No other countries have experienced the same tremendous expansion of agroecology as Brazil did, during years the agroecological movement was also able to establish rural schools based on sustainable agricultural practices, various national meetings and scientific societies (PETERSEN et al, 2013; ALTIERI \& TOLEDO, 2011). Since 2003 agroecology started also to be recognized formally by the national government in the legislation related to organic agriculture such as an important tool to boost and empower smallholding agriculture (DE MEDEIROS HESPANHOL, 2008), meanwhile the Brazilian authority for research on agriculture (Empresa Brasileira de Pesquisa Agropecuária -EMBRAPA) has acknowledged agroecology officially as both an interdisciplinary science and a social movement for the promotion of sustainable development through the use of traditional knowledge (WEZEL et al, 2009). EMBRAPA introduced programs to foster sustainable agriculture in the whole country through agroecology using a systemic and a participatory approach to integrate small farmers' knowledge in agroecosystem and agrobiodiversity management (ALTIERI \& TOLEDO, 2011). Nevertheless, there are not specific law and policies yet for a sustainable agroecological transition of the country (SAQUET, 2008; DE MEDEIROS HESPANHOL, 2008), even that the Brazilian agroecological movements are expanding considerably its use in the south of the country with important results in Paranà, Rio Grande do Sul and Santa Catarina (WEZEL et al., 2009; FRITZ, 2008).

Consumers in Brazil are not well informed on sustainability in agriculture and they do not look very sensitive on this issue yet, slowing down the transition toward agroecology (ARL, 2008). Furthermore, national media do not sustain agroecology both minimizing in the news the externalities of conventional agriculture and stigmatizing farmers' movements activities (PICINATTO, 2008). In addition, many smallholding farmers did not embrace agroecology practices because they are unaware of the socio-economic improvements that they could obtain with the use of it slowing further the transition to sustainable agriculture (HESPANHOL, 2008; ALTIERI, 1999; SAQUET, 2008).

\section{MULTI-STAKEHOLDER APPROACH FOR RURAL DEVOLOPEMNT. THE CASE STUDY OF THE EAST REGION OF MINAS GERAIS}

Socio-ecological systems are extremely complex to be governed only with a vertical approach, Cork Declaration highlighted the importance of coordination among several level of intervention encouraging the use of bottom-up and multi-stakeholder approaches (CORK DECLARATION, 2016). The Organisation for Economic Co-Operation and Development (OECD) stated in the "New Rural Paradigm" that because of the multitude of objectives intrinsic in rural policies multi-level cooperation and multisectorial approaches are fundamentals to obtain effective results, recommending to consider the diverse 
interests and capabilities of the different stakeholders involved in rural development in order to improve the policy effectiveness (OECD, 2006). Multi-actor governance can be adapted easily to local and endogenous peculiarities and needs increasing the legitimacy and transparency of the policies empowering local communities (KOOPMANS et al., 2017). The multitude of actors and interests involved in rural development require collective actions of cooperation for the design of self-determined and shared rules in order to permits that policies and shared result will last in the long period, instead of using a vertical approaches that might not fit on the real necessities of the whole system of the context that it should not be considered only local, but also regional, national and international because of the spacial and temporal relations with other external actors (SAINT VILLE et al, 2017). Even the importance of multi-stakeholder approach in the policy making activity, it complicates the whole process more complicated and less standardized than before, with the risk of incurring in significant costs and high probability of failure without a proper management of it (KOOPMANS et al, 2017).

A good example of a successful multi-stakeholder approach for rural development is the international cooperation project, between the Italian Foreign Affair Ministry and the Brazilian government, called "Agroecology and socio-environmental education for sustainable development" that has been developed in the East Region of Minas Gerais (MG) state in Brazil. The aim of the project was supporting the use of agroecology for the sustainable development of the area through the joint activity of several stakeholders with different level of intervention.

The project started in the municipalities of Manhuaçu, Conceição de Ipanema, Simonésia, Caratinga, San Joao de Manhuaçu (Figure 1). The economy of the area in which the project has been developed is totally based on coffee production, $60 \%$ of the population is employed in agriculture and the $97 \%$ the local production of value deriving from coffee production and $99 \%$ of the agricultural land cultivated with coffee, equal to forty thousand hectares of land (IBGE, 2006; IBGE, 2010). Brazil is the largest coffee producer in the world, on average between the 1990 and 2016 it produced 38.4 million of green coffee bags equal to $32 \%$ of the total production worldwide (ICO, 2016). MG produce half of Brazilian coffee, in 2015 it was 51\% of the total (MAPA, 2015), with a big contribution of smallholding farmers who represents the $88 \%$ of the total agricultural productive units in MG (IBGE, 2006). Land ownership in the region is in prevalence formed by small property less than 10ha small farming is the $85 \%$ in number of 5.899 units (whereas non-small farming units were 1.046 units) of the total agricultural units of the region contributing substantially to the total local production of coffee (IBGE, 2006; IBGE, 2010). Coffee is principally cultivated with not-shaded monoculture plantation using intensive method imported with the Green Revolution involving the use of high level of fertilizers and pesticides. 
Figure 1. The Area of the project: the East Region of Minas Gerais.

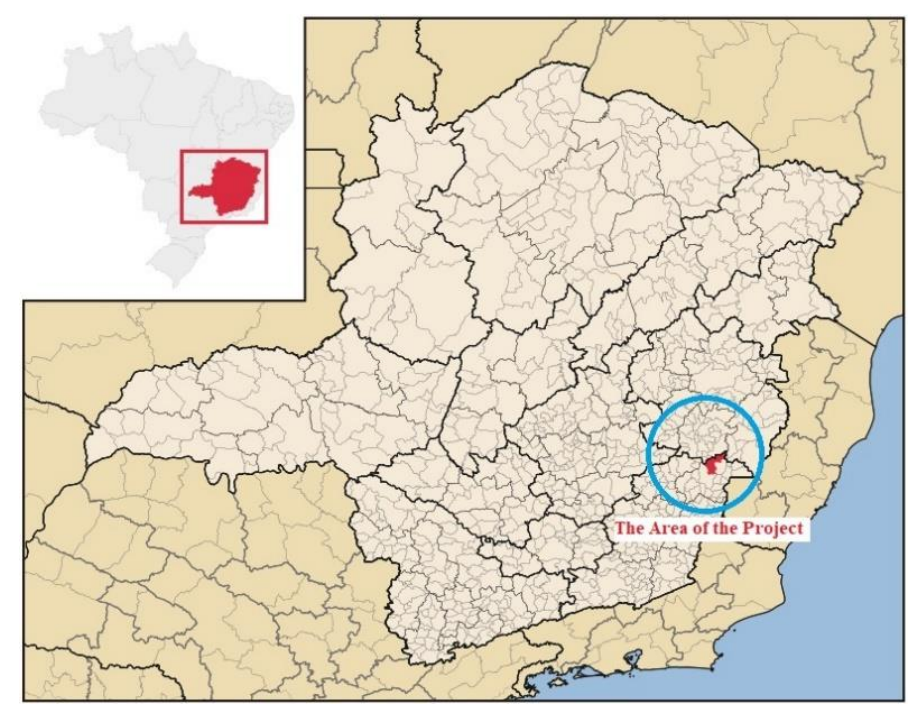

Source: https://pt.wikipedia.org/.

Coffee production is affected by high volatile markets and bottle neck on the value chain which highly influence income generation for local coffee small farmers (VORLEY, 2003), the strong dependency of the economy of the area in coffee production depends on small farmers, improvements of their economic condition would positively reflect on a wider regional scale.

Agriculture, and coffee production, is the main driver of deforestation in the area of the Mata Atlântica biome, the local tropical forest, extremely important for biodiversity conservation and the provision of ecological services, but which is highly fragmented and endangered by anthropic pressures in all Brazil (SILVANO et al, 2005).

The above brief description can represent well the socio-ecological context of the area, that is characterized by a high level of complexity, because if, on one hand there is the necessity of fostering coffee sector that is extremely important for the local economy, on the other hand, the local ecosystems suffer high fragility.

In the last decade some local farmers imported agroecology experimenting new techniques in order to reduce environmental pressures and improve their economic conditions through a systemic approach in coffee production, after good results farmers using agroecological practices increased by word of mouth and farmer networks consolidating a small agroecological vanguard point in the area. The project sustained these initial experiences of agroecology started in few small communities with the objective of scale them up on a regional base by using a multi-stakeholder approach. The principal goal of the project was to foster the creation of a multi-level network of actors in order to contribute to the sustainable development of the area considering both its socio-economic and environmental dimension in an intergenerational view. 
The principal focus was to empower local stakeholders in activating and continuing the process of "agroecologization" of the area giving them tools to self-organize themselves in order to give sustainability of the project in the future. Other activities were related to technical transmission of knowledge to be replicated by farmers using Campesino a Campesino (CAC) model as a rural pedagogy and network building approach (HOLT-GIMÈNEZ, 2008).

The international cooperation project officially started in 2008 and concluded in 2013, before the beginning of it several meetings have been realized between the Italian NGO RE.TE. and the Brazilian counterpart REDE de Tecnologia alternativa to consider all the principal local actors to involve them in the initial activities, and then increase actors' participation in the project through snowball technique to consolidate a strong network of stakeholders cooperating with shared objectives. When the initial network of actors has been sketched the NGOs started to find funding to sustain the implementation of the activity through a project proposal seeking for institutional support through the cooperation agreements between Italy and Brazil

The stakeholders involved have been informal farmers group, farmers' organizations and cooperatives, rural trade union, single farmers, rural communities and representative of the municipalities.

The project operated as a platform for the transmission of knowledge among the stakeholders through workshops, meetings and local fairs; in which agroecological practices and natural resource management techniques were presented and thought horizontally and in a participative manner to farmers by experts, academics, agronomist and technicians from other farmer organization working with agroecology or Ngos. Trainers were from local areas, but most of them arrived from other part of MG and some from other part of Brazil highlighting the multi-level approach assumed by the project. Subjects of teaching have been no tillage, agroforestry, crop rotation, water conservation, integrated pest management, intercropping, green manure and green pesticide, production diversification, introduction of small animals, product commercialization on local markets and food processing to add value to farmers' products. Local social promoters have been trained for helping in farmers' organization in the use of governmental programs for smallholding farming aids, principally on PNAE, PAA and PRONAF.

The knowledge and practical information on agroecology gained by local farmers were replicated locally by the same persons who receive formation in their own community, and afterwards with exchange through communities in order to spread the use of it at higher scale level. Those were important occasions of network building for the local stakeholders, because even if they were geographically close most of them did not have the chance to cooperate between each other before, because of material difficulties they have to cope with such as lack of financial resources to organize meetings, difficulties in transportation and lack of methodologies in collective actions. 
In order to give intergenerational sustainability a crucial actor was the "Escola Familia Agricola EFA Margarida Alves" a farming school for children which use the agroecology approach for its educational activities.

The two private forest reserve - Reserva Particular do Patrimônio Natural (RPPN) - in Simonésia and Caratinga have been involved for boosting environmental activities with partners of the project, in disseminating of information on ecological problems and in creating nurseries for native trees to be implanted in farms for woodlands afforestation in order to create an ecological corridor between the two natural reserves enlarging the habitat of various endangered animals. All stakeholders involved in the project are evidenced in Table 1.

Table 1. Stakeholders of the international cooperation project.

\begin{tabular}{|c|c|c|c|}
\hline Name & Type & Dimension & Location \\
\hline Rede Ecovida & Non governmental Organisation & Nacional & Tres Cachoeiras \\
\hline OPL & $\begin{array}{l}\text { Farmer organization } \\
\text { Farmer and Rural Workers Trade }\end{array}$ & Local & Caratinga \\
\hline Sindicato (STR) de Simonésia & Union & Local & Simonésia \\
\hline Università de Viçosa & University & Regional & Viçosa \\
\hline EFA Margarida Alves ensino primario & $\begin{array}{l}\text { Agroecological school for Farmers' } \\
\text { children }\end{array}$ & Local & $\begin{array}{l}\text { Conceição de } \\
\text { Ipanema }\end{array}$ \\
\hline EFA Margarida Alves ensino secundário & $\begin{array}{l}\text { Agroecological school for Farmers' } \\
\text { children }\end{array}$ & Local & $\begin{array}{l}\text { Simonésia } \\
\text { Conceição de }\end{array}$ \\
\hline Comunidad Corrego do Funil & Farmer organization & Local & Ipanema \\
\hline Rappresentantes municipais & Representatives of the municipalities & Local & All municipalities \\
\hline Comunidad de Eliotas & Farmer organization & Local & Simonésia \\
\hline Comunidad de San Vicente & Farmer organization & Local & Simonésia \\
\hline Grupo informal dos Deniz & Farmer organization & Local & Simonésia \\
\hline Cooperativa Garibaldi & Farmer cooperative & Nacional & Curitiba \\
\hline Cooperativa Aecia & Farmer cooperative & Nacional & Curitiba \\
\hline Cooperativa Econativa & Farmer cooperative & Nacional & Curitiba \\
\hline COORPOL & Farmer cooperative & Local & Caratinga \\
\hline Agrifas & Farmer cooperative & Local & Simonésia \\
\hline $\begin{array}{l}\text { Associação de Mulheres de San Vicente } \\
\text { (AFAM) }\end{array}$ & Farmer organization & Local & $\begin{array}{l}\text { Simonésia } \\
\text { Conceicão de }\end{array}$ \\
\hline COOPERSOL & Farmer cooperative & Local & $\begin{array}{l}\text { Ipanema } \\
\text { Conceição de }\end{array}$ \\
\hline APROCAFIR & Farmer organization & Local & Ipanema \\
\hline RPPN Mata do Sossego & Environmental protected Area & Local & Simonésia \\
\hline RPPN Feliciano Abdalla & Environmental protected Area & Local & $\begin{array}{l}\text { Caratinga } \\
\text { San Joao de }\end{array}$ \\
\hline Grupo informal S. Joao de Manhuaçu & Farmer organization & Local & Manhuaçu \\
\hline RE.TE. ONG & Non governmental Organisation & International & Turin (Italy) \\
\hline REDE de Tecnologia Alternativas & Non governmental Organisation & Nacional & Belo Horizonte \\
\hline Italian Ministry of Foreign Affairs & Institution & International & Rome (Italy) \\
\hline Brazilian Government & Institution & Nacional & Brasilia \\
\hline
\end{tabular}


The project operated with a multi-level approach in which different stakeholders were cooperating themselves, both inter levels and intra levels with different tasks, duties and responsibilities. The levels of intervention at which each actor operated can be divided into three frameworks:

- Institutional (Italian Ministry of Foreign Affairs and the Brazilian Government) with legal, financial and control obligations;

- Networking (the two NGOs promoter of the projects) with task of advocacy, empowering, managing, training, communication intra stakeholders and accountability.

- Operational (Farmers organizations and cooperatives, Rural Communities, Trade Unions, Environmental Protected Areas, Farmers' children School, University of Viçosa, Local Municipalities) with duties on training and education, multiplication of knowledge, implementation of agroecological practices, experimentation for solving local agricultural problems, self-representation, external communication and networking building.

The different levels in which the stakeholders operated are represented in Figure 2.

Figure 2. Stakeholders divided into frameworks of activity of the project.

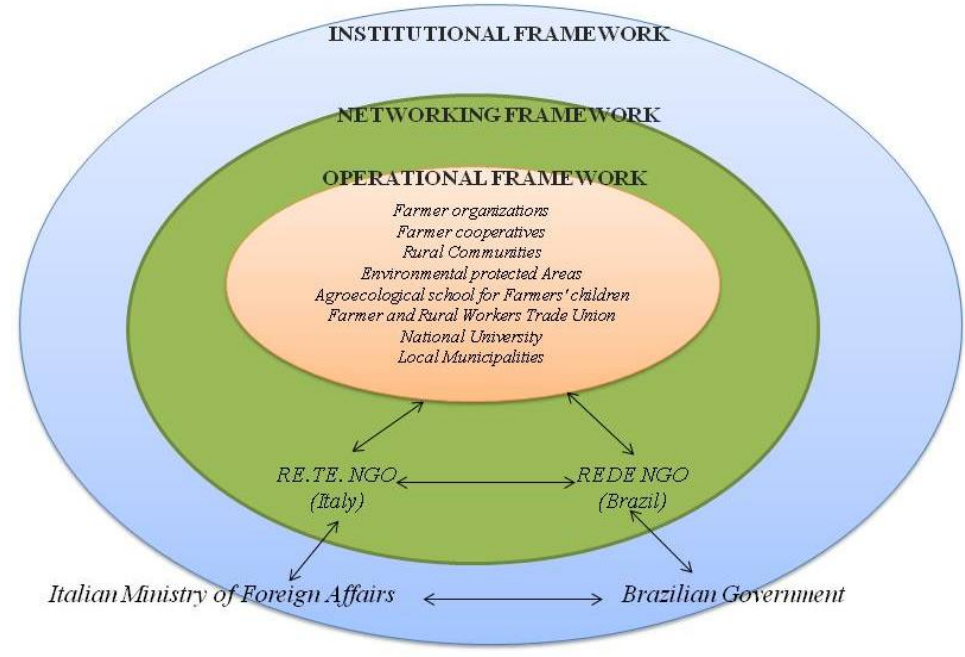

By means of the project 182 families of farmer in 30 different communities received direct agroecological training and education through 35 courses on agroecology, 18 community leaders operate as agroecological knowledge propagators, 5 municipality representatives have been trained on agroecology for rural development and 13 farmers organizations have been strengthening in food processing and marketing strategies. Several greenhouse and coffee dryers have been self-built with collective work activities among different farmers communities, 5 laboratories for food processing to be sold through PNAE program have been built and many small farms have started a transition through agroecology reducing the use of pesticide and fertilizers. 
The Brazilian NGO REDE de intercâmbio Tecnologia Alternativas open a local permanent office in Simonésia training local expert and to work as local staff with the aim of operating directly on the territory and being an important mediator for the transition towards agroecology for local farmers.

The best results gained by the project was that, after the end of the activities and with the interruption of financial aids from the Italian cooperation sector, the Brazilian stakeholders continued to collaborate each other to pursue the transition towards agroecology. A new EFA school of secondary level have been built to give continuity for the students of the primary school, now students receiving agroecology education are totally 120 per year. Three other projects on agroecology have been started with the financial sustain of Brazilian government aid for development and private charities, they allowed to reinforce the already existing network of farmers involving 980 farmers for each project and enlarging the area of intervention to other two municipality of Santana do Manhuaçu and São José do Mantimento. Five farmer families converted totally to agroecology and 120 families are in transition towards agroecology and the farmers' organization working (informal groups and associations) on the area for agroecology transition are now 45.

\section{CONCLUSIONS}

The results obtained by the international cooperation project are important for a small region as the East Region of MG and they can represent a good step toward a sustainable rural development supporting in the area of intervention both, the socio-economic improvements of small farmers and preserving the environment at the same time. This was possible only with a bottom-up approach and multi-stakeholder rural development process in which all actors operating in different frameworks cooperated for a common shared objective dividing tasks, duties and responsibilities to better adapt at the real local condition. In less than 10 years it has been done what, both federal and local governments, have never been able to do for at least forty years since the introduction of coffee in the area. Even this process it is in its primordial phase of development, a scaling-up on regional base of agroecology seems now possible.

This experience could be replicated in other context either in Brazil or abroad to sustain agroecological and grass roots farmers' movements in order to obtain sustainable and fair development of rural areas. Multi-stakeholder approach represents a new paradigm for rural development, and can give important results to assign responsibility to the entire network of local actors in order to give continuity to the process even after the end of strong financial and institutional support. Further studies should analyze the multi-stakeholder approach for rural development, analyzing key elements for the success of these activities to outline practical tools to be matched to agroecology in order to give 
elements of replication to support the scaling up of agroecological practices and food sovereignty in the global food system.

\section{REFERENCES}

ALTIERI M.A., 1991. Agroecologia. Prospettive scientifiche per una nuova agricoltura. Franco Muzzio \& C. Editore spa, Padova (It).

ALTIERI M., 1999. Applying agroecology to enhance the productivity of peasant farming systems in Latin America. Environment, Development and Sustainability 1, 197-117.

ALTIERI, 2009. Agroecology, Small Farms, and Food Sovereignty. Monthly Review 61.

ALTIERI M.A., TOLEDO V., 2011. The agroecological revolution in Latin America: rescuing nature, ensuring food sovereignty and empowering peasant. The Journal of Peasant Studies 38(3), 587-612.

ALTIERI M.A., FUNES-MONZONTE F.R., PETERSEN P., 2012. Agroecologically efficient agricultural systems for smallholder farmers: contributions to food sovereignty, Agronomy for Sustainable Development 32(1), 1-13.

ALTIERI M. \& NICHOLLS C., 2005. Agroecology and the Search for a Truly Sustainable Agriculture. Basic textbooks for environmental training, University of California, Berkeley (USA).

ARANHA A., 2010. Fome Zero: a project turned into a government strategy. In Da Silva J. (eds), "The Fome Zero (Zero Hunger) program. The Brazilian experience", MDA 2010, Brasilia.

ARL V., 2008. Agroecologia: desafios para uma condiçao de interaçao positiva e co-evoluçao humana na natureza. In Alves A. eds), "Desenvolvimento territorial e agroecologia", Editora Expressao popular Ltda 2008, Sao Paulo.

BEUCHELT T.D \& VICHOW D, 2012. Food sovereignty or the human right to adequate food: which concept serves better as international development policy for global hunger and poverty reduction?, Agric Hum Values 29, 259-273.

BROWN L., 2011. The New Geopolitics of Food. From the Middle East to Madagascar, high prices are spawning land grabs and ousting dictators. Welcome to $21^{\text {st }}$-century food wars. Foreign Policy. http://foreignpolicy.com/2011/04/25/th e-new-geopolitics-of-food/ (Accessed on July 2017)
CAPORALI F., 2008. Ecological agriculture: human and social context. In Clini C. et al.(ed.), Sustainable Development and Environmental Management: Experiences and case studies, Springer. 415-429.

CORK DECLARATION, 2016. A Better Life in Rural Areas.

DA SILVA J., 2010. The Zero Hunger project: a proposal for a food security policy for Brazil. In Da Silva J. (eds) ,"The Fome Zero (Zero Hunger) program. The Brazilian experience", MDA 2010, Brasilia.

DE SCHUTTER 0., 2009. Mission to Brazil. Report of the Special Rapporteur on the right to food, Oliver De Schutter. General Assembly 19 February 2009.

DE SCHUTTER O., 2010. REPORT OF THE SPECIAL RAPPORTEUR ON THE RIGHT OF FOOD, United Nation General Assembly, Gen 2010.

DALGAARD T., HUTCHINGS N.J., PORTER J., 2003. Agroecology, scaling and interdisciplinarity, Agriculture, Ecosystem and Environment, 100, 3951.

DELGADO A., 2008. Opening up for Participation in Agro-Biodiversity Conservation: The Expert-Lay in a Brazilian Social Movement, Journal of Agriculture and Environmental Ethics 21, 559577.

DEL GROSSI M.E., 2012. Poverty reduction: from 44 million to 29.6 million people. In Da Silva J. (eds), "The Fome Zero (Zero Hunger) program. The Brazilian experience", MDA 2010, Brasilia. Ù

DE MEDEIROS HESPANHOL R., 2008. Agroecologia:limites e perspectivas. In Alves A. (eds), "Desenvolvimento territorial e agroecologia", Editora Expressao popular Ltda 2008, Sao Paulo.

DUPRAZ C. L. \& A. POSTOLLE, 2013. Food sovereignty and agricultural trade policy commitments: How much leeway do West African nations have?. Food Policy 38, 115-125.

ELVER H., 2015. Promotion and protection of human rights: human rights questions, including alternative approaches for improving the effective enjoyment of human rights and fundamental freedoms. Interim report of the Special Rapporteur on the right to food. United Nation General Assembly $70^{\text {th }}$ session, A/70/287, August 2015. 
FA0, 2009a. The state of agricultural commodity markets. Food and Agriculture Organization of the United Nation, Rome(It).

FAO, 2009b. 1.02 billion people hungry. Food and Agriculture Organization of the United Nation. http://www.fao.org/news/story/en/item/20568 /icode/ (Accessed on July 2017).

FAO, 2015a. The State of Food Insecurity in the World. Meeting the 2015 international hunger targets: taking stock of uneven progress. Food and Agriculture Organization of the United Nation, Rome (It).

FAO, 2015b. FAO Statistical Pocketbook 2015. World Food and Agriculture. Food and Agriculture Organization of the United Nation, Rome(It).

FAO, 2016. Summary for decision-makers. FAO Regional Symposia on Agroecology. Food and Agriculture Organization of the United Nation.

FRANCIS C., RICKERL D., LIEBLEIN G., SALVADOR R., GLIESSMAN S. , WIEDENHOEFT M., BRELAND T. A., SIMMONS S. , CREAMER N. , ALLEN P., HARWOOD R., ALTIERI M., SALOMONSSON L. , FLORA C., HELENIUS J., POINCELOT R., 2003. Agroecology: The Ecology of Food Systems, Journal of Sustainable Agriculture, vol. 22 n. 3, pp.99-118.

FRITZ N., 2008. Agroecologia: o desenvolvimento no Sudeste do Paranà. In Alves A.

(eds),"Desenvolvimento territorial e agroecologia", Editora Expressao popular Ltda 2008, Sao Paulo.

GLIESSMAN S., 1990. Agroecology:research the ecological basis for sustainable agriculture. Springer-Verlag New York Inc., Madison, Wisconsin(USA).

GODFRAY H.C., BEDDINGTON J.R., CRUTE I.R., HADDAD L., LAWRENCE D., MUIR J..F., PRETTY J., ROBINSON S., THOMAS S.M., TOULMIN C., 2010. Food Security: The Challange of Feeding 9 Billion People. Science 37, 812-818.

HESPANHOL A., 2008. Desafios da geraçao de renda em pequenas propriedades e a questao do desenvolvimento rural sustentavel no Brasil. In Alves A. (eds), "Desenvolvimento territorial e agroecologia", Editora Expressao popular Ltda 2008, Sao Paulo.

HOLT-GIMENEZ E., 2002. Measuring farmers' agroecological resistance after Hurricane Mitch in Nicaragua: a case study in participatory, sustainable land management impact monitoring. Agriculture, Ecosystem and Environment 93,87105.

HOLT-GIMÈnEZ E., 2008. Campesino a Campesino. Voces de Latinoamérica. Movimiento Campesino a Campesino para la Agricultura Sustentable. Food First Book, Managua(Nica).
HOLT-GIMENÈZ E. \& PATEL R., 2010. Food Rebellions!La Crisi E La Fame Di Giustizia. Slow Food Editore, Bra (It).

HOLT GIMÉNZ AND SHATTUCK, 2011. Food crises, food regimes and food movements: rumblings of reform or tides of transformation?, The Journal Peasant Studies 38(1):109-44.

HOLT-GIMÈNEZ E. \& ALTIERI M., 2013. Agroecology, food sovereignty, and the new green revolution, Agroecology and Sustainable Food Systems 37(1), 90-102.

IATP, 2013. Scaling Up Agroecology. Toward the realization of the right to food. Minneapolis (Mi), Institute for Agriculture and Trade Policy.

IBGE, 2000. Estatisticas do XX seculo.

IBGE, 2010. Sintese de indicadores sociais.Uma analise das condiçoes de vida da populaçao brasileira. Estudos e pesquisas, Informaçao Demografica e Socioeconomica numero 27. Rio de Janeiro, 2010.

IBGE, 2011. Indicadores demograficos e da saude. Comunicaçao social 16 de novembro de 2011.

IBGE, 2012. Os Indigenas no Censo demografico 2010. Primeiras consideraçoes com base no quesito cor ou raça.

ICO, 2016. Trade Statistics Tables, International Coffee http://www.ico.org/trade_statistics.asp (Accessed on July 2017)

IFAD, 2011. Rural Poverty Report 2011. New realities, new challenges: new opportunities for tomorrow's generation, The International Fund for Agricultural Development (IFAD), Rome (It),.

IFAD \& UNEP, 2013. Smallholders, food security, and the environment. International Fund for Agricultural Development (IFAD).

KOOPMANS M.E., ROGGE E., METTEPENNING E., KNICKEL S.S., 2017. The role of multi-actor governance in aligning farm modernization and sustainable rural development, Journal of rural studies, in press, https://doi.org/10.1016/j.jrurstud.2017.03.012.

LAMINE C., DAROLT M., BRADENBURG A., 2012. The Civic and Social Dimension of Food Production and Distribution in Alternative Food Networks in France and Southern Brazil, International Journal of Sociology of Agriculture and Food 19 (3), 383401.

LOSANO M., 2007. Il movimento Sem Terra del Brasile. Funzione sociale della proprietà e latifondi occupati. Edizioni Diabasis, Reggio Emilia (It).

MAZOYER M. \& ROUDART L.,2006. A history of world agriculture. From the neolithic age to the current crisis. Earthscan, Sterling (USA).

MARTINE G. \& MCGRANAHAN G., 2010. Brazil's early urban transition: what can it teach urbanizing countries? IIED and UNFPA. 
MAPA, 2015. Informe Estatístico do Café. Ministério da Agricoltura, Pecuària e Abastecimento. http://www.agricultura.gov.br/acesso-ainformacao/acoes-e-programas/cartas-deservico/politica-cafeeira/informe-estatistico-docafe (Accessed on July 2017)

NAGAYETS 0., 2005. Small farms: Current Status and Key Trends. Proceedings of the Future of Small Farms Research Workshop Wye College, June 2629, 2005.

NELSON E., SCOTT S., CUKIER J., LEYVA GALÀN A., 2008. Institutionalizing agroecology: successes and challenges in Cuba, Agriculture Human Value 26, 233-243.

ODUM E.P.,1966. Ecologia. Nicola Zanichelli S.p.a., Bologna.

OECD, 2006. The New Rural Paradigm. Policies and Governance. OECD Rural Policy Reviews, Organisation for Economic Co-Operation and Development.

OXFAM, 2010. Fighting hunger in Brazil Much achieved, more to do.

PATEL, 2009. What does food sovereignty look like?, The journal of peasant studies 36(3), 663- 706.

PAULINO E.T., 2014. The agricultural, environmental and socio-political repercussions of Brazil's land governance system, Land Use Policy 36, 134-144.

PERACI A. \& BITTENCOURT G., 2010. Family farming and price guarantee programs in Brazil: the food procurement program (PAA). In Da Silva J. (eds) ,"The Fome Zero (Zero Hunger) program. The Brazilian experience", MDA 2010, Brasilia.

PETERSEN P., MUSSOI E.M., DAL SOGLIO F., 2013. Institutionalization of the Agroecological Approach in Brazil: Advances and Challenges, Agroecology and Sustainable Food Systems 37, 102-114.

PICCINATO A., 2008. Agroecologia no Paranà: evoluçao e desafios. In Alves A. (eds), "Desenvolvimento territorial e agroecologia", Editora Expressao popular Ltda 2008, Sao Paulo.

PIMBERT M.P., 2008. Towards Food Sovereignty. Reclaiming autonomous food systems. London (Uk), IIED.

PRETTY J., NOBLE A.D., BOSSIO D., DIXON J., HINE R.E., PENNING DE VRIES F.W., MORRISON J.I., 2006. ResourceConserving agriculture increases yields in developing countries, Environmental Science and Technology 40 (4), 1114-1119.

PRESIDENCIA DA REPUBLICA BRASILEIRA, 2006a. LEI № 11.326, DE 24 DE JULHO DE 2006.

PRESIDENCIA DA REPUBLICA BRASILEIRA, 2006b. DECRETO $\mathrm{N}^{\circ} 5.996$ DE $20 \mathrm{DE}$ DEZEMBRO DE 2006.
PRESIDENCIA DA REPUBLICA BRASILEIRA, 2009. LEI N ${ }^{\circ} 11.947$ DE 16 DE JUNHO DE 2009.

PRESIDENCIA DA REPUBLICA BRASILEIRA, 2012. DECRETO N ${ }^{\circ} 7.775$, DE 4 DE JULHO DE 2012.

RIO DECLARATION, 1992. Report of the united nations conference on environment and development. The Rio Declaration on Environment and Development 1992. Rio de Janeiro, 3-14 June 1992.

RIO DECLARATION, 2012. The Future We Want. Outcome document of the United Nations Conference on Sustainable Development. Rio de Janeiro, Brazil, 20-22 June 2012.

ROSSET P.M., 2003. Food Sovereignty. Global Rallying cry of farmers movements. Food First Backgrounder 9(4).

ROSSET P.M., 2008. Food Sovereignty and the contemporary food crisis. Development 51 (4), 460-463.

ROSSET P., MACHIN SOSA B., ROQUE JAIME A.M., AVILA LOZANO D.R., 2011. The Campesino to Campesino agroecology movement of ANAP in Cuba: social process methodology in the construction of sustainable agriculture and food sovereignty, The Journal of Peasant Studies 38 (1), 161-191.

ROCHA C., BURLANDY L., MALUF R., 2012. Small farms and sustainable rural development for food security: The Brazilian experience, Development Southern Africa 29(4).

SAINT VILLE A., HICKEY G.M., PHILLIP L.E., 2017. How do stakeholder interactions influence national food security policy in the Caribbean? The case of Saint Lucia, Food Policy 68, 53-64.

SAQUET A., 2008. Reflexoes sobre a agroecologia no Brasil. In Alves A. (eds),"Desenvolvimento territorial e agroecologia", Editora Expressao popular Ltda 2008, Sao Paulo.

SHAH A., 2008. Global Food Crisis 2008. Global Issue. http://www.globalissues.org/article/758/globalfood-crisis-2008 (Accessed on July 2017).

SHIVA V.,1991. The violence of the Green Revolution. Third world agriculture, Ecology and Politics. Zed Books. London (GB).

SILVANO R., UDVARDYB S., CERONIC M., FARLEYD J. 2005. An ecological integrity assessment of a Brazil Atlantic Forest watershed based on a surveys of stream health and local farmers' perceptions: implication for management, Ecological Economics 53 (3), 369 - 385.

SOARES P., DAVÒ-BLANES M.C., MARTINELLI S.S., MELGAREJO L., CAVALLI S.B., 2017. The effect of new purchase criteria on food procurement for the Brazilian school feeding program, Appetite 108, 288-294. 
SOCLA, 2012. The scaling up of agroecology: spreading the hope for food sovereignty and resiliency. A contribution at Rio+20 on issues at the interface of hunger, agriculture, environment and social justice.

UPHOFF N., 2002. Agroecological Innovations. Increasing food production with participatory development, Earthscan Publications Ltd, London (UK).

UN, 2011. The Report on the World Social Situation 2011: The Global Social Crisis. Department of Economic and Social Affairs. United Nations New York, 2011

VORLEY B., 2003. Food, inc. Corporate concentration from farm to consumer. Uk Food Group.

WEZEL A. \& SOLDAT V., 2009. A quantitative and qualitative historical analysis of the scientific discipline of agroecology, International Journal of Agricultural Sustainability, vol. 7, n. 1, pp. 3-18.

WEZEL A., BELLON S., DORÉ T., FRANCIS C., VALLOD D., DAVID C. 2009. Agroecology as a science, a movement and a practice. A review. Agronomy for Sustainable Development 29, 503-515.

WORLD BANK, 2013. World development report 2013. Jobs. The World Bank, Washington DC (USA).

WORLD BANK, 2017. Data Poverty and Equity. http://povertydata.worldbank.org/poverty/count ry/BRA (accessed on July 2017).

WTO, 2013. World Trade Organization International Trade Statistics 2013. https://www.wto.org/english/res_e/statis_e/its2 013_e/its13_toc_e.htm (Accessed on July 2017). 